\title{
Development of $\mathrm{Ce} / \mathrm{La}_{0.25} \mathrm{Sr}_{0.75} \mathrm{Cr}_{0.5} \mathrm{Mn}_{0.5} \mathrm{O}_{3}$ Anode Catalyst for Further Application in Solid Oxide Fuel Cell Typed Reactor
}

\author{
W. Appamana
}

\begin{abstract}
La}_{0.25} \mathrm{Sr}_{0.75} \mathrm{Cr}_{0.5} \mathrm{Mn}_{0.5} \mathrm{O}_{3} \quad$ (LSCM) and Ce/LSCM were synthesized and investigated for their potential use in an oxidative coupling of methane (OCM) reaction. The catalysts was characterized using XRD, SEM and Impedance. The catalytic activity of catalysts for OCM reaction was both studied in fixed bed and SOFC reactor. A YSZ was used as a solid electrolyte and $\mathrm{La}_{0.8} \mathrm{Sr}_{0.2} \mathrm{FeO}_{3}$ (LSF) was used as a cathode material. The cell obtained a maximum power density of 221 $\mathrm{mW} \mathrm{cm}{ }^{-2}$ in humidified methane. The cell was put under a bias voltage of $0.3 \mathrm{~V}$, which $\mathrm{C} 2$ hydrocarbon was generated from the cell. At the highest methane conversion rate, the cell achieved a good C2 hydrocarbon selectivity of $78.4 \%$ and a $\mathrm{C} 2$ yield of $3.4 \%$ at $850^{\circ} \mathrm{C}$.
\end{abstract}

Index Terms-SOFC reactor, cogeneration, C2 hydrocarbon, LSCM.

\section{INTRODUCTION}

Research on the oxidative coupling of methane (OCM) has increased in intensity over the past decade due to the potential for converting natural gas directly to higher value chemicals, such as ethylene and ethane (C2 hydrocarbon) [1], [2]. The conversion of methane to $\mathrm{C} 2$ hydrocarbons remains a challenging problem in heterogeneous catalysis and chemical reaction engineering. The selectivity to C2 hydrocarbon decreases with increasing methane conversion. In addition, the yield of $\mathrm{C} 2$ hydrocarbons achieved in a fixed-bed reactor (FBR) was limited to about $20-25 \%$ due to to the presence of undesired complete oxidation in the gas phase and partially on the catalyst surface [3], [4]. In the last 25 years, numerous works have been reported and several innovative approaches have been proposed, including the use of solid electrolyte membrane reactors [5], [6]. However there are a few researches reveled SOFC reactor to produce C2 hydrocarbons. The SOFC reactor for co-generation of $\mathrm{C} 2$ hydrocarbons and electric power was first reported by Pujare and Sammells, they studied the OCM by using the cell $\mathrm{Pt} / \mathrm{Sm}_{2} \mathrm{O}_{3} / \mathrm{La}_{0.89} \mathrm{Sr}_{0.10} \mathrm{MnO}_{3} / \mathrm{YSZ} / \mathrm{La}_{0.89} \mathrm{Sr}_{0.10} \mathrm{MnO}_{3} / \mathrm{Pt}$. High selectivity to $\mathrm{C} 2$ hydrocarbon (90 \%) was achieved although the methane conversion was relatively low [7]. Hence, a

Manuscript received January 15, 2017; revised May 4, 2017

The author was with Center of Excellence in Catalysis and Catalytic Reaction Engineering, Department of Chemical Engineering, Faculty of Engineering, Chulalongkorn University, Bangkok 10330, Thailand. She is now with the Department of Chemical Engineering, Rajamangala University of Technology Thanyaburi, Pathumtani, 12110 Thailand (e-mail: weerinda.a@en.rmutt.ac.th). development of anode catalysts for an oxidative coupling of methane in SOFC becomes an important goal to improve the conversion, selectivity, yield and stability of the reactor. Addition, the anode material must require good electronic conductivity, high electrochemical activity and structural stability properties [8].

Perovskite structure $\left(\mathrm{ABO}_{3}\right)$ anode materials have received much attention because of their mixed electronic and ionic conduction behaviors that make the triple-phaseboundary (TPB) extend to the entirely exposed anode surface. Among the variety of these oxides, $\mathrm{LaSrMnO}_{3}$ -based perovskite compounds are promising Ni-free anode candidates due to their high chemical stability at high temperatures under both oxidizing and reducing atmospheres, and strong resistance to carbon deposition [9], [10]. However, they suffer from the disadvantages of low electronic and ionic conductivities and poor catalytic activity. The sufficient electronic and ionic conductivities are indispensable to reduce the electrode polarization and thus promote the electrode reaction process. There are many efforts to enhance the electronic and ionic conductivities of $\mathrm{LaSrMnO}_{3}$ material. For example donor doping on the $\mathrm{Mn}$ site of $\mathrm{LaSrMnO}_{3}$ with perovskite structure could improve the electrical conductivity [11]-[15]. S.W. Tao and co-worker reported the increasing in electrical conductivity of doping on the $\mathrm{Mn}$ site of $\mathrm{LaSrMnO}_{3}$. Moreover doped-chromium on $\mathrm{Mn}$ site is suitable for high temperature operation $\left(750-900^{\circ} \mathrm{C}\right)$ because $\mathrm{Cr}$ doped $\mathrm{LaSrMnO}_{3}$ played a vital role in increasing resistance to coking (as well as raising sulphur tolerance) [16]. Moreover, Ceria doped perovskite material, the electrochemical catalytic performance and carbon deposition resistance in oxidation of syngas were significantly improved [17].

In this work, $\mathrm{Ce} / \mathrm{La}_{0.25} \mathrm{Sr}_{0.75} \mathrm{Cr}_{0.5} \mathrm{Mn}_{0.5} \mathrm{O}_{3}$ (Ce/LSCM) were examined. The surface morphology, composition and surface area were characterised by several techniques. The catalytic activity of catalysts for oxidative coupling of methane reaction and the influence of some operating variables, i.e., the temperature were investigated in detail over a fixed bed reactor. For SOFC cell preparation, the cell components was improved by tape- casing preparation. The ohmic resistance decreased by the reduction of the electrolyte thickness. Finally, the electrochemical performance was investigated in solid oxide fuel cell reactor (SOFC).

\section{EXPERIMENTAL}

\section{A. $\mathrm{La}_{0.25} \mathrm{Sr}_{0.75} \mathrm{Cr}_{0.5} \mathrm{Mn}_{0.5} \mathrm{O}_{3}$ Catalyst Preparation}

The perovskite oxide, $\mathrm{La}_{0.25} \mathrm{Sr}_{0.75} \mathrm{Cr}_{0.5} \mathrm{Mn}_{0.5} \mathrm{O}_{3}$ (LSCM), 
was prepared by sol-gel method. In this process, stoichiometric quantities of $\mathrm{La}\left(\mathrm{NO}_{3}\right)_{3} \cdot 6 \mathrm{H}_{2} \mathrm{O}$ (Aldrich, 99.99\%), $\mathrm{Mn}\left(\mathrm{NO}_{3}\right)_{2} \cdot 6 \mathrm{H}_{2} \mathrm{O}$ (Aldrich, 98\%), $\mathrm{Cr}\left(\mathrm{NO}_{3}\right)_{2} \cdot 6 \mathrm{H}_{2} \mathrm{O}$ (Aldrich, 99.99\%), and $\mathrm{Sr}\left(\mathrm{NO}_{3}\right)_{2}$ (Aldrich, 99.99\%) precursors were dissolved into water. Hence, an aqueous solution of citric acid (Riedel de Haën, reagent grade) and ethylene glycol (Aldrich, 98\%) was added to the metal solution (citric acid: metal nitrates [acetate]: ethylene glycol molar ratios $=5: 1: 4.3$ ). The mixture was stirred at $70{ }^{\circ} \mathrm{C}$ for 12 h. Water was slowly evaporated on a hot plate and the resulting brown gel was dried and then heated up in air at $400{ }^{\circ} \mathrm{C}$ for $2 \mathrm{~h}$ in an oven. LSCM perovskite samples were obtained by ball-milling the decomposed resin for a few hours before calcination at $1000^{\circ} \mathrm{C}$ for $2 \mathrm{~h}$ in air with heating rate $\left.6{ }^{\circ} \mathrm{C} / \mathrm{min}\right)$.

\section{B. Catalysts Characterization}

XRD patterns of the $\mathrm{La}_{0.25} \mathrm{Sr}_{0.75} \mathrm{Cr}_{0.5} \mathrm{Mn}_{0.5} \mathrm{O}_{3}$ (LSCM) catalyst were obtained by using X-ray diffractometers, D 5000 (Siemens AG) using $\mathrm{Cu} K \alpha$ radiation equipped with $\mathrm{Ni}$ filter with a range of detection of $2 \theta=20-80$ and a resolution of $0.02^{\circ}$. X-ray diffractometer connected with a personal computer using Diffract AT version 3.3 for a full control of the XRD analyzer. SEM (model JEM-6400 Jeol Ltd., Japan) techniques were used to study the catalyst morphology. The SEM was operated in the back scattering electron (BSE) mode at $15 \mathrm{kV}$.

\section{Catalytic Activity Measurement}

The catalytic of oxidative coupling of methane over LSCM catalysts was performed at atmospheric pressure and at temperatures of $700-900{ }^{\circ} \mathrm{C}$ in a quartz micro-reactor (i.d. 6 $\mathrm{mm}$ ) placed in a ceramic tube furnace. A total of $0.3 \mathrm{~g}$ of fresh catalyst was loaded into a reactor that was located in a programmable furnace with a thermocouple placed in the center of the catalyst bed, and 4:1:5 $\mathrm{CH}_{4}: \mathrm{O}_{2}: \mathrm{N}_{2}$ molar ratios of the feed were used. The gas products were sampled every 30 min for measuring their compositions using an on-line gas chromatography equipped with a TCD detector.

\section{Preparation of LSF//YSZ//LSCM and LSF//YSZ// Ce-LSCM Single Cell}

The single cell was prepare in YSZ 3-layer cells electrolyte and porous similar in somewhere [13]. LSCM was added to anode porous layers using aqueous nitrate solutions until the loading of LSCM was 40 wt.\%. Then, the sample was transferred to the furnace where the nitrate decomposition was performed in a stagnant air. The heating treatment consisted of heating rate of $3{ }^{\circ} \mathrm{C} / \mathrm{min}$ to $1200{ }^{\circ} \mathrm{C}$ and dwelling at this temperature for $2 \mathrm{hrs}$ before cooling down to room temperature. After the heating treatment, the perovskite of the electrode material should deposit on the YSZ porous scaffold surface. For cathode side, $\mathrm{La}_{0.8} \mathrm{Sr}_{0.2} \mathrm{FeO}_{3}$ (LSF) cathode was added after the final $1200{ }^{\circ} \mathrm{C}$ calcinations used to produce the LSCM, and was calcined at $850{ }^{\circ} \mathrm{C}$. Additions of $\mathrm{CeO}_{2}$ at the anode were impregnated in separate stages. In this case, the drying temperature was $400{ }^{\circ} \mathrm{C}$, and they were calcined at $700{ }^{\circ} \mathrm{C}$. Phase composition and metal oxide distribution inside the porous substrate were investigated by SEM-EDS.

\section{E. Performance of SOFC Cell}

In this study, $\mathrm{H}_{2}$ and $\mathrm{CH}_{4}$ were used as the anode gas. Humidified $\mathrm{H}_{2}$ and $\mathrm{CH}_{4}$ were achieved by bubbling gas through room-temperature water resulting in a gas mixture of $3 \% \mathrm{H}_{2} \mathrm{O}$ and fuel. The flow rate of gas was controlled by a mass flow meter.

The open circuit voltage (OCV) of the cell under testing condition was recorded as a function of time until the system reached the steady state before performing the electrochemical measurements. The electrochemical measurements were carried out using a frequency response analyzer (Solartron 1255, UK) coupled with an electrochemical interface (Solartron 1287, UK). The voltage-current (V-I) measurement was performed by sweeping potentials across the cell using a scan rate of 2 $\mathrm{mV} / \mathrm{sec}$ with the applied potentials from $0-0.5 \mathrm{~V}$ with respect to the OCV. The AC impedance measurement was obtained in a frequency range of $1 \mathrm{MHz}$ to $0.1 \mathrm{~Hz}$ using potential amplitude of $50 \mathrm{mV}$ under open-circuit conditions. In some cases, the polarisation under applied potential was also investigated.

For C2 hydrocarbon synthesis, humidified $\mathrm{CH}_{4}$ was fed into the anode, during electrolysis, the gaseous products in the anode outlet stream were examined by a mass spectrometer (MS) (Prolab, Thermo Scientific) and GC-8A gas chromatograph (Shimadzu) equipped with a TCD, using a Poropak Q and Molecular Sieve 5A column at every 15 min.

\section{RESUlTS AND DISCUSSION}

\section{A. Catalytic Performance of Catalysts in Fixed Bed Reactor}

The results of reactant conversions and product selectivities of LSCM and Ce/LSCM catalysts for OCM are shown in Fig. 1. This compares the catalytic performances of catalysts between $700-900^{\circ} \mathrm{C}$. The WHSV and molar ratio of $\mathrm{CH}_{4}: \mathrm{O}_{2}: \mathrm{N}_{2}$ were kept at $10000 \mathrm{ml} \mathrm{g}^{-1} \mathrm{~h}^{-1}$ and 4:1:5, respectively. The results show LSCM catalyst was more selective to partial oxidation than the oxidative coupling of methane reaction, as the selectivity to $\mathrm{CO}$ was much higher than that to $\mathrm{CO}_{2}$. Approximately $54.5 \%$ CO selectivity and $43.2 \% \mathrm{CO}_{2}$ selectivity at $43.2 \% \mathrm{CH}_{4}$ conversion with LSCM successfully obtained at $850{ }^{\circ} \mathrm{C}$. For Ce/LSCM catalyst, it was more selective to oxidative coupling of methane reaction, as the selectivity to $\mathrm{C} 2$ was much higher than that to $\mathrm{CO}$ and $\mathrm{CO}_{2}$. Approximately 54.5\% CO selectivity and 43.2\% $\mathrm{CO}_{2}$ selectivity at $43.2 \% \mathrm{CH}_{4}$ conversion with LSCM successfully obtained at $850{ }^{\circ} \mathrm{C}$. In an analogous manner, Ce promoter addition increased methane conversion and $\mathrm{C} 2$ hydrocarbon selectivity. The $\mathrm{C}^{+}$selectivity increased when Ce was present in the catalyst. The highest $\mathrm{C}^{+}$(55.3\%) selectivity were measured at $800{ }^{\circ} \mathrm{C}$.

The effect of temperature on products is presented in Fig. 2. $\mathrm{C}^{+}$selectivity increased with temperature and passed through a maximum at $800{ }^{\circ} \mathrm{C}$. For undesirable products, $\mathrm{CO}_{2}$ selectivity decreased with $\mathrm{Ce}$ addition. The $5 \mathrm{wt} \% \mathrm{Ce}$ catalyst demonstrated the lowest $\mathrm{CO}_{2}$ selectivity at $750{ }^{\circ} \mathrm{C}$. The yield of C2 hydrocarbon selective products as a function 
of temperature can be seen in Fig. 2. C2 hydrocarbon yield increased and passed through a maximum value at $800{ }^{\circ} \mathrm{C}$. Consequently, the addition of Ce promoter could promote the performance of the catalysts for the OCM reaction, and inhibited the gas phase oxidation of methane.

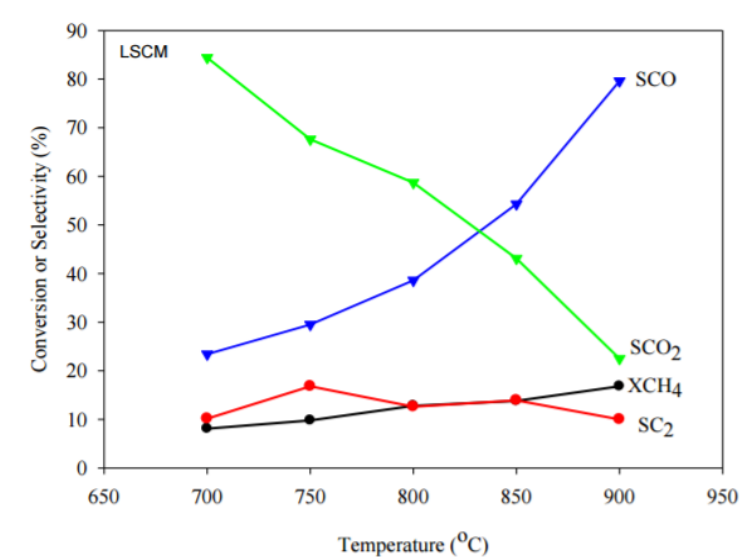

Fig. 1. The catalytic performance of LSCM catalyst as related to operation temperatures at WHSV of $10000 \mathrm{mlg}-1 \mathrm{~h}-1$ and $\mathrm{CH}_{4} / \mathrm{O}_{2}$ of 4 .

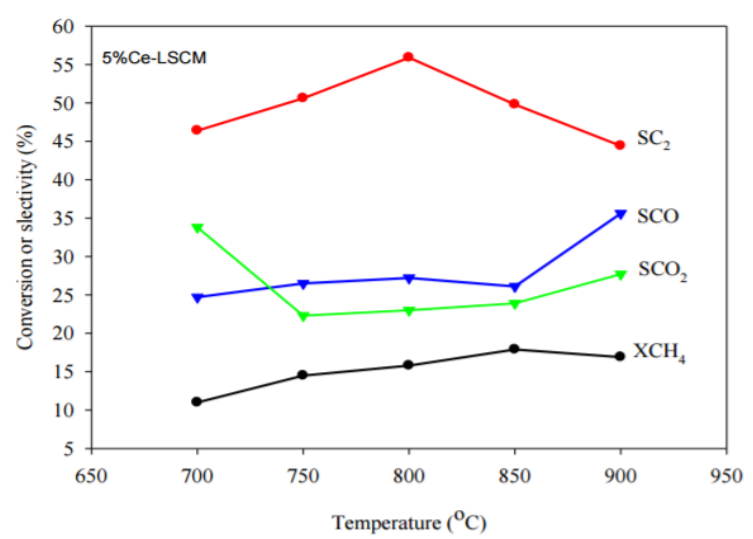

Fig. 2. The catalytic performance of Ce/LSCM catalyst as related to operation temperatures at WHSV of $10000 \mathrm{mlg}-1 \mathrm{~h}-1$ and $\mathrm{CH}_{4} / \mathrm{O}_{2}$ of 4 .

\section{B. Characterization of SOFC Single Cell}

Phase identification of perovskite electrodes prepared from metal nitrates was determined by X-ray diffraction (XRD). Fig. 3 displays the XRD patterns from the surfaces of two electrode composites comprising of LSCM and Ce-LSCM addition into electrodes. For comparison, an XRD pattern of the YSZ porous layer is also included. After the sintered at $1200{ }^{\circ} \mathrm{C}$, XRD peaks of LSCM were showed in Fig. 3. For $\mathrm{CeO}_{2}$ doping, the $\mathrm{CeO}_{2}$ peaks can be detected at $2 \theta$ as $28.6^{\circ}$. These data indicated that the addition of $\mathrm{Ce}$ promoter was not reacted with LSCM phase.

\section{Microstructure of Impregnated Electrodes}

Firstly, the firing conditions for the impregnation of the LSCM electrode were investigated. According to the literatures [18], [19], the thermal decomposition of nitrate solution in air begins at $300{ }^{\circ} \mathrm{C}$. With an intention of prevent any thermal shock that may happen in this fairly strong ceramic membrane after repeated impregnation, the decomposition temperature of the impregnated nitrate was set at $350{ }^{\circ} \mathrm{C}$ with dwell time of $30 \mathrm{~min}$. However after several impregnation cycles, the impregnated samples were completely disintegrated and delaminated. The SEM images in Fig. 4 show a significant change in the microstructure of porous layers, the SEM images of the structures LSCM indicates that the LSCM forms a uniform coating over the surfaces of the YSZ (Fig. 4a). For $\mathrm{CeO}_{2}$ loading, the results show the presence of nanocrystalline $\mathrm{CeO}_{2}$ (Fig. 4b). The estimated particle diameters for $\mathrm{CeO}_{2}$ were $5-21 \mathrm{~nm}$ and uniform coating over the surfaces of the LSCM/YSZ.

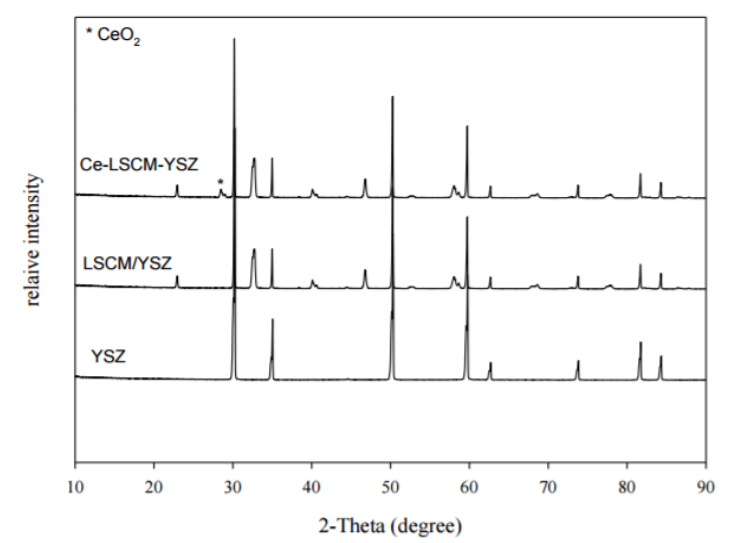

Fig. 3. The XRD pattern of (a) YSZ, (b) LSCM/YSZ and (c) Ce-LSCM/YSZ.
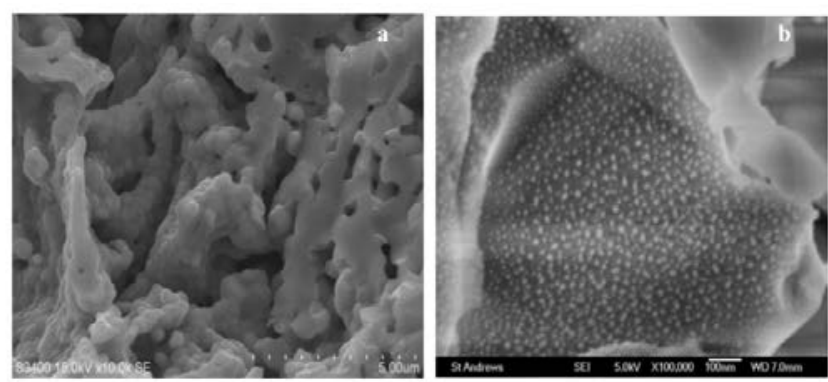

Fig. 4. SEM images of fracture-cross section of YSZ membrane with an impregnated porous layer. (a) porous membrane with LSCM impregnated layer, (b) porous membrane with Ce/LSCM impregnated layer.

\section{Electrochemical Performances}

Fig. 5 shows voltage, current, and power density properties for tape-cast SOFC cells fabricated by impregnation of $\mathrm{LSCM}$ with $\mathrm{CeO}_{2}$ and without $\mathrm{CeO}_{2}$ with $\mathrm{Ag}$ current collectors. The measurements of these cells at $800{ }^{\circ} \mathrm{C}$ are shown in Fig. 5. Their open circuit voltage (OCV) values were $\sim 1.02-1.08 \mathrm{~V}$, which were very close to the theoretical value calculated from the Nernst equation. Such high OCV values indicate that a dense structure is well-formed in the YSZ electrolyte and leakage of the fuel gas is negligible for each sample. As seen in Fig. 6, the power density using a LSCM anode catalyst was $123 \mathrm{~mW} \mathrm{~cm}^{-2}$ at $800{ }^{\circ} \mathrm{C}$. When 5 wt\% of $\mathrm{CeO}_{2}$ was impregnated together with LSCM, the power density was $298 \mathrm{mWcm}^{-2}$. This is because the added ceria enhanced the conductivity, as well as extended effective active areas. As shown in Fig. 6, the cell had a series resistance, $R_{S}$, of $0.65 \Omega . \mathrm{cm}^{2}$ and a total resistance, $R_{T}$, of 1.05 $\Omega . \mathrm{cm}^{2}$ at $750{ }^{\circ} \mathrm{C}$. As the temperature increased to $850{ }^{\circ} \mathrm{C}$, the series resistance of the cell decreased to $0.37 \Omega . \mathrm{cm}^{2}$ and the total resistances decreased to $0.65 \Omega . \mathrm{cm}^{2}$. All the impedance spectra captured at OCV with varying temperatures demonstrated that the resistance of the cell was greatly dominated by the polarization resistance. The power density, with respect to the temperature, for the SOFC systems studied is shown in Fig. 7. In SOFC systems studied, there is an increase in the maximum power with increasing 
temperature. The addition $\mathrm{f}$ ceria catalysts improve performance across the entire temperature range studied. The highest power density achieved in this study were for the cell containing $5 \mathrm{wt} \% \mathrm{CeO}_{2}$ with $356 \mathrm{~mW} \cdot \mathrm{cm}^{-2}$ at $850{ }^{\circ} \mathrm{C}$ in humidified $\mathrm{H}_{2}$. These high powder densities are achieved because ceria is the most active materials for effective catalysis of the different processes in fuel oxidation.

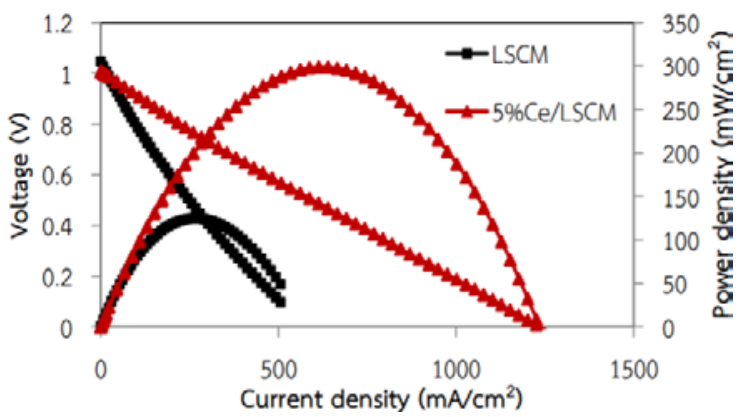

Fig. 5. Performance curves of the 8 YSZ cell with $40 \mathrm{wt} \% \mathrm{LSCM}(\mathrm{a})$ and $5 \% \mathrm{Ce} / \mathrm{LSCM}$ (b) in wet humidified $\mathrm{H}_{2}$ at $800^{\circ} \mathrm{C}$.

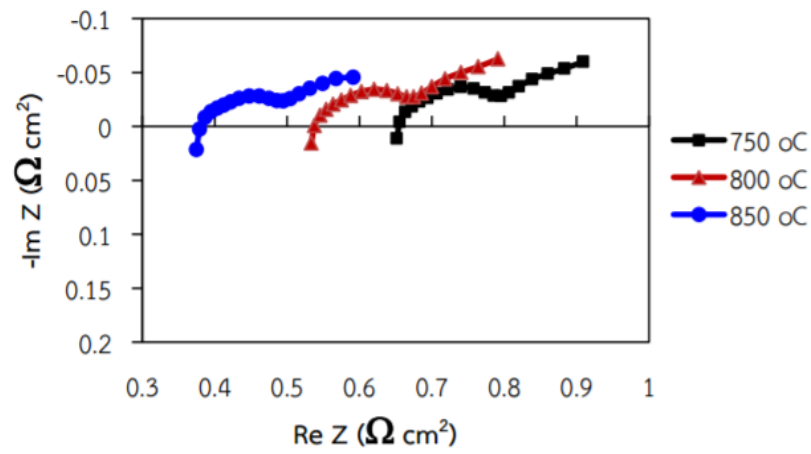

Fig. 6. Impedance spectra of the cell with 5\%ceria-40wt\% LSCM as anode and $40 \mathrm{wt} \% \mathrm{LSF}$ as cathode in humidified $\mathrm{H}_{2}$ at different temperatures.

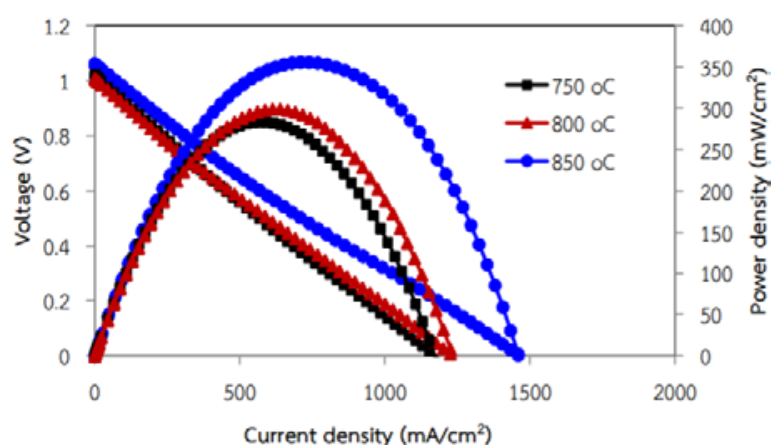

Fig. 7. IV and performance curves of the cell with 5\%ceria-40wt\% LSCM as anode and $40 \mathrm{wt} \% \mathrm{LSF}$ as cathode in humidified $\mathrm{H}_{2}$ at different temperatures.

E. SOFC with $5 \% \mathrm{CeO}_{2} / \mathrm{LSCM}$ Anode as Cogeneration of Chemical and Electricity

The 8YSZ cell with the $200 \mu \mathrm{m}$ porous scaffolds were infiltrated with $40 \mathrm{wt} \% \mathrm{LSF}$ and $5 \% \mathrm{CeO}_{2}-40 \mathrm{wt} \% \mathrm{LSCM}$ was used to investigate the performance of the $5 \% \mathrm{CeO}_{2}-40$ wt\% LSCM anode as a cogeneration device. The cell was tested in humidified $\mathrm{CH}_{4}$ following at the rate of $10 \mathrm{ml} / \mathrm{min}$ at $750-850{ }^{\circ} \mathrm{C}$. Impedance spectra of the cell presented in Fig. 8 shows that the maximum power with increasing temperature. The cell had a low resistance and also the highest maximum

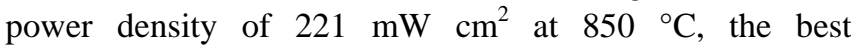
performance was also obtained at $850{ }^{\circ} \mathrm{C}$ in humidified $\mathrm{CH}_{4}$ (Fig. 9). As shown in Table I, the methane conversion was $3.1 \%$ after applying $0.3 \mathrm{~V}$ to the cell for 30 minutes. At the highest methane conversion rate, the cell achieved a good C2 hydrocarbon selectivity of $78.4 \%$ and a $\mathrm{C} 2$ yield of $3.3 \%$ at $850{ }^{\circ} \mathrm{C}$.

TABLE I: THE ARRANGEMENT OF CHANNELS

\begin{tabular}{lllll}
\hline \hline $\begin{array}{l}\text { Temperature } \\
\left({ }^{\circ} \mathrm{C}\right)\end{array}$ & $\mathrm{X}_{\mathrm{CH} 4}(\%)$ & $\mathrm{S}_{\mathrm{C} 2}(\%)$ & $\mathrm{S}_{\mathrm{CO} 2}(\%)$ & $\mathrm{Y}_{\mathrm{C} 2}(\%)$ \\
\hline 800 & 3.1 & 69.8 & 25.8 & 2.6 \\
900 & 3.4 & 78.4 & 16.7 & 3.3 \\
\hline \hline
\end{tabular}

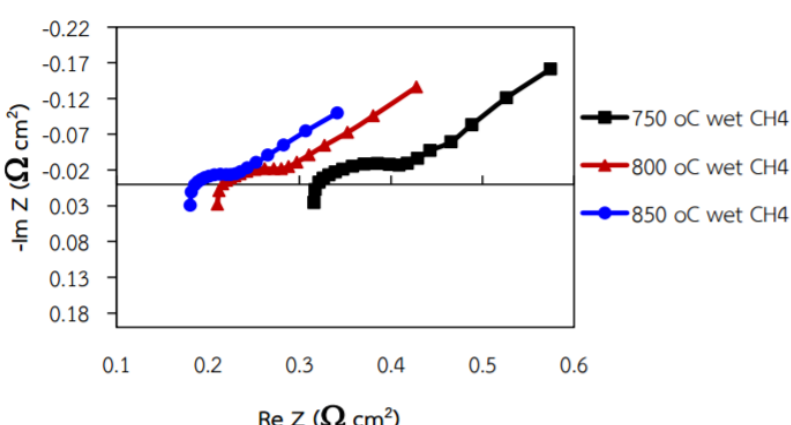

Fig. 8. Impedance spectra of the cell with 5\%ceria-40wt\% LSCM as anode and $40 \mathrm{wt} \% \mathrm{LSF}$ as cathode in humidified $\mathrm{CH}_{4}$ at different temperatures.

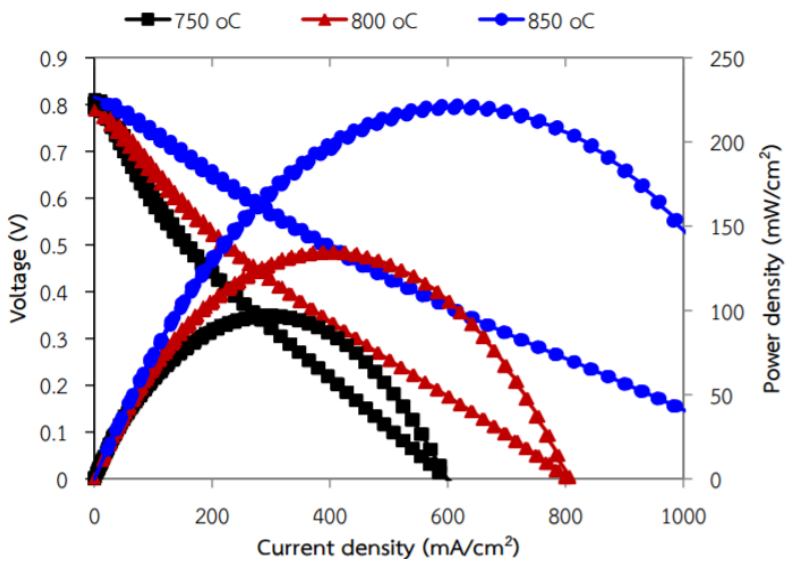

Fig. 9. IV and performance curves of the cell with 5\%ceria-40wt\% LSCM as anode and $40 \mathrm{wt} \% \mathrm{LSF}$ as cathode in humidified $\mathrm{CH}_{4}$ at different temperatures.

\section{CONCLUSION}

The catalytic activity for oxidative coupling of methane (OCM) was measured in a fixed bed reactor (FBR) and solid oxide fuel cell reactor (SOFC). Approximately 54.5\% CO selectivity and $43.2 \% \quad \mathrm{CO}_{2}$ selectivity at $43.2 \% \quad \mathrm{CH}_{4}$ conversion with LSCM successfully obtained at $850{ }^{\circ} \mathrm{C}$ for Ce/LSCM catalyst. The addition of Ce promoter could promote the performance of the catalysts for the OCM reaction, and inhibited the gas phase oxidation of methane. The improvement of cell performance was carried out by decreasing the thickness of the electrolyte and using a high catalytic activity electrode. The tape casting method was employed in order to reduce the electrolyte thickness and prepare porous ceramic support for the electrode material. The electrode materials were introduced into porous YSZ support by ion impregnation technique and a composite electrode/electrolyte was achieved. The impregnated LSCM was synthesized at temperatures over $700{ }^{\circ} \mathrm{C}$ and did not react with $8 Y S Z$ at $1200{ }^{\circ} \mathrm{C}$. Tape-cast SOFCs with impregnated LSCM exhibited excellent performance when $\mathrm{CeO}_{2}$ was used as catalysts. A SOFC with a composite anode $5 \% \mathrm{CeO}_{2}-40$ 
wt\% LSCM exhibited maximum power density $221 \mathrm{~mW} \mathrm{~cm}^{-2}$ at $850{ }^{\circ} \mathrm{C}$ in humidified methane. Under a load of $0.3 \mathrm{~V}, 3.4 \%$ $\mathrm{CH}_{4}$ conversion and 78.4\% C2 selectivity were obtained.

\section{ACKNOWLEDGMENT}

W. Appamana would like to thank the Rajamangala University of Technology Thanyaburi (RMUTT) research foundation scholarship in 2015. The author would like to thank Professor John T. S. Irvine, Professor Suttichai Assabamrungrat and Center of Excellence on Catalysis and Catalytic Reaction Engineering, Department of Chemical Engineering, Chulalongkron University.

\section{REFERENCES}

[1] T. W. Elkins, S. J. Roberts, and H. E. Hagelin-Weaver, "Effects of alkali and alkaline-earth metal dopants on magnesium oxide supported rare-earth oxide catalysts in the oxidative coupling of methane," Applied Catalysis A: General, vol. 538, pp. 175-190, Nov. 2016.

[2] N. Hiyoshi and K. Sato, "Oxidative coupling of methane over $\mathrm{Mn}-\mathrm{Na}_{2} \mathrm{WO}_{4} / \mathrm{SiO}_{2}$ catalyst with continuous supply of alkali chloride vapor,” Fuel Processing Technology, vol. 51, pp. 148-154, Oct. 2016.

[3] J. Wang et al., "Comparative study on oxidation of methane to ethane and ethylene over $\mathrm{Na}_{2} \mathrm{WO}_{4}-\mathrm{Mn} / \mathrm{SiO}_{2}$ catalysts prepared by different methods," Journal of Molecular Catalysis A: Chemical, vol. 245, pp. 272-277, 2006.

[4] Z. Fakhroueian, F. Farzaneh, and N. Afrookhteh, "Oxidative coupling of methane catalyzed by $\mathrm{Li}$, $\mathrm{Na}$ and $\mathrm{Mg}$ doped $\mathrm{BaSrTiO}_{3}$," Fuel, vol. 87, pp. 2512-2516, 2008.

[5] T. Tagawa et al., "Design of electrode for solid oxide fuel cells reactor," Solid State Ionics, vol. 106, pp. 227-235, 1998.

[6] L. Zhang, C. Yang, A. I. Frenkel, S. Wang, G. Xiao, K. Brinkman, and F. Chen, "Co-generation of electricity and chemicals from propane fuel in solid oxide fuel cells with anode containing nano-bimetallic catalyst,” Journal of Power Sources, vol. 262, pp. 421-428, 2014.

[7] A. S. Carrillo, T. Tagawa, and S. Goto, "Application of mist pyrolysis method to preparation of $\mathrm{Ni} / \mathrm{ZrO}_{2}$ anode catalyst for SOFC type reactor,” Materials Research Bulletin, vol. 36, pp. 1017-1027, 2001.

[8] K. Chen, N. Ai, and S. P. Jiang, "Performance and stability of $(\mathrm{La}, \mathrm{Sr}) \mathrm{MnO}_{3}-\mathrm{Y}_{2} \mathrm{O}_{3}-\mathrm{ZrO}_{2}$ composite oxygen electrodes under solid oxide electrolysis cell operation conditions," International Journal of Hydrogen Energy, vol. 37, pp. 10517-10525, 2012.

[9] T. Wu, B. Yu, W. Zhang, J. Chen, and S. Zhao, "Fabrication of a high-performance nano-structured $\mathrm{Ln}_{1-\mathrm{x}} \mathrm{Sr}_{\mathrm{x}} \mathrm{MO}_{3-\delta}(\mathrm{Ln}=\mathrm{La}, \mathrm{Sm} ; \mathrm{M}=$
Mn, Co, Fe) SOC electrode through infiltration,” RSC Advances, vol. 6, pp. 68379-68387, 2016.

[10] S. Barison et al., "Novel Au/ $\mathrm{La}_{1-x} \mathrm{Sr}_{x} \mathrm{MnO}_{3}$ and $\mathrm{Au} / \mathrm{La}_{1-x} \mathrm{Sr}_{x} \mathrm{CrO}_{3}$ composites: Catalytic activity for propane partial oxidation and reforming," Solid State Ionics, vol. 177, pp. 3473-3484, 2007.

[11] G. Corre et al., "Activation and ripening of impregnated manganese containing perovskite SOFC electrodes under redox cycling," Chemistry of Materials, vol. 26, pp. 1077-1084, 2009.

[12] G. Kim et al., "Investigation of the structural and catalytic requirements for high-performance SOFC anodes formed by infiltration of LSCM," Electrochemical and Solid-State Letters, vol. 12, pp. B48-B52, 2009.

[13] S. Lee et al., "Solid oxide fuel cell cathodes prepared by infiltration of $\mathrm{LaNi}_{0.6} \mathrm{Fe}_{0.4} \mathrm{O}_{3}$ and $\mathrm{La}_{0.91} \mathrm{Sr}_{0.09} \mathrm{Ni}_{0.6} \mathrm{Fe}_{0.4} \mathrm{O}_{3}$ in porous yttria-stabilized zirconia," Journal of Power Sources, vol. 193, pp. 747-753, 2009.

[14] C. Yang et al., "Characterization of infiltrated $\left(\mathrm{La}_{0.75} \mathrm{Sr}_{0.25}\right)_{0.95} \mathrm{MnO}_{3}$ as oxygen electrode for solid oxide electrolysis cells," International Journal of Hydrogen Energy, vol. 35, pp. 5187-5193, 2010.

[15] H. He et al., "Low-temperature fabrication of oxide composites for solidoxide fuel cells," Journal of the American Ceramic Society, vol. 87, pp. 331-336, 2004.

[16] S. Barison et al., "Novel $\mathrm{Au} / \mathrm{La}_{1-x} \mathrm{Sr}_{x} \mathrm{MnO}_{3}$ and $\mathrm{Au} / \mathrm{La}_{1-\mathrm{x}} \mathrm{Sr}_{\mathrm{x}} \mathrm{CrO}_{3}$ composites: Catalytic activity for propane partial oxidation and reforming,” Solid StateIonics, vol. 177, pp. 39-40, 2007.

[17] S. Tao and J. T. S. Irvine, "Synthesis and characterization of $\mathrm{La}_{0.75} \mathrm{Sr}_{0.25}$ $\mathrm{Cr}_{0.5} \mathrm{Mn}_{0.5} \mathrm{O}_{3-8}$, a redox-stable, efficient perovskite Anode for SOFCs," Catal. Sci. Technol., vol. 151, pp. A252-A259, 2004.

[18] B. L. Farrell and S. Linic, "Oxidative coupling of methane over mixed oxide catalysts designed for solid oxide membrane reactors," Catalysis Today, vol. 6, pp. 4370-4376, 2016.

[19] P. E. De. Miranda et al., "A method for the production of light hydrocarbons from gas with high methane content, a solid oxide fuel cell used for the production of light hydrocarbons from gas with high methane content, and a catalyst for the production of ligh hydrocarbons from gas with high methane content," Google Patents, 2010.

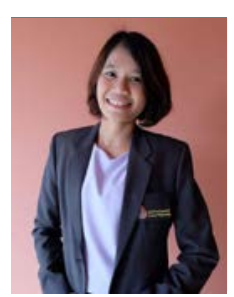

Weerinda Appamana was born in 1984. Now, she is a lecturer at the Department of Chemical Engineering, Rajamangala University of Technology Thanyaburi, Pathumtani, 12110 Thailand. She earned her Ph.D degree in chemical engineering from Chulalongkorn University, Thailand. Dr. Weerinda Appamana's interests cover: waste to energy generation; intensification process; catalysis and catalytic reaction engineering. 